\title{
Reading through Films
}

\author{
Madhavi Gayathri Raman (Corresponding author) \\ Dept. of Materials Development, School of English Language Education, \\ The English and Foreign Languages University, Hyderabad, India \\ E-mail: gayathriraman@yahoo.com \\ Vijaya \\ School of English Language Education, \\ The English and Foreign Languages University, Lucknow, India \\ E-mail: vijuciefl@gmail.com
}

Doi:10.7575/aiac.alls.v.7n.1p.168

Received: 26/09/2015

URL: http://dx.doi.org/10.7575/aiac.alls.v.7n.1p.168

Accepted: 30/11/2015

\begin{abstract}
This paper captures the design of a comprehensive curriculum incorporating the four skills based exclusively on the use of parallel audio-visual and written texts. We discuss the use of authentic materials to teach English to Indian undergraduates aged 18 to 20 years. Specifically, we talk about the use of parallel reading (screen-play) and audiovisual texts (Shawshank Redemption, and Life is Beautiful, A Few Good Men and Lion King) drawn from popular culture in the classroom as an effective teaching medium. Students were gradually introduced to films based on novels with extracts from the original texts (Schindler's List, Beautiful Mind) for extended reading and writing practice. We found that students began to pay more attention to aspects such as pronunciation, intonational variations, discourse markers and vocabulary items (phrasal verbs, synonyms, homophones, and puns).
\end{abstract}

Keywords: Reading, films, popular culture, ESL classroom, language skills

\section{Introduction}

Certain themes appeal to the human mind across cultures bridging linguistic barriers. They can become a strong binding force inspite of the tensions created by the texts due to cultural differences. Some of the common favourite themes that emerged in our experience of using films in language classrooms are psychological disorders, human suffering, and triumph of good over evil. While English films transport the students to an unfamiliar world and culture, the themes provide vitality and sustenance to class. India due to it's colonial past and presence of classical English literature in the syllabi even at the school level, is not totally oblivious to literature from other cultures.

Indian learners are an interesting case in second language and literacy development. Most adolescent and adult L2 learners in language classrooms in the US and other countries have exposure to the target language and opportunities to listen to and speak English but may have little or no print literacy. In contrast, a large majority of Indian L2 learners are introduced to the language through the print medium. These learners, who often go on to become proficient users of English, learn to write and read their first words even before they articulate them. The learning of first words in the language happens simultaneously with the development of writing and reading without much exposure to the spoken form of the language outside the class. A possible reason for this lies in the history of English language teaching in India, dating back to the work of Michael West and the immense popularity of the Structural method with its overemphasis on the learning of structures through reading and writing. Consequently, listening and speaking received little or no attention in class. Adding to this is the low spoken proficiency levels of the teachers (NCF, 2005) and inadequate infrastructure facilities.

Until recently, listening and speaking was not a part of the English curriculum in India. Even now a majority of classrooms tend to be devoid of listening activities. In cases where listening is incorporated in the syllabus, the tasks are limited to boring routine texts like news reports, railway announcements and so on. The use of films in Indian undergraduate classrooms in our case stemmed not so much from a desire to introduce the students to other cultures and texts as from a purely pragmatic decision to combine interesting listening tasks in the classroom with paralinguistic cues to aid learning.

The use of authentic materials, and films in particular, for language teaching finds support in a number of studies (Martinez, 2002; Baharani \& Sim, 2012; Brinton, 1991; Golden, 2001; Ryan, 1998). Some of the advantages involved in the use of authentic materials in the ESL context are as follows: 
(i) authentic language samples in the form of songs and films serve to bridge the gap between the language classroom and the real world for ESL students. They can also be exposed to language varieties such as British, American, Australian English etc. and this can serve as the basis for discussions in class with regard to pronunciation, stress, intonation and so on. It also helps learners to see how their variety differs from others and which aspects of language they need to work on in order to be intelligible to other non-native or native speakers of the language.

(ii) As our study too shows, authentic materials are known to raise the motivation levels of the learners. According to a study by Melvin and Stout (1987), the use of authentic materials for the study of culture not only increased students' motivation to learn but also increased their confidence and helped them to understand the practical benefits of being able to use the language in real world contexts. According to Nunan (1999) and Gilmore (2007), it is essential for learners to have exposure to various kinds of authentic material because it helps to motivate them by bringing content and subject matter to life.

(iii) authentic materials in the forms of cartoons and films (Clark, 2000; Doring, 2002; Rule \& Ague, 2005; Ryan, 1998; Ismaili, 2013) engage the attention of the learners and present information in a non-threatening atmosphere. By lowering the affective filter (Krashen, 1985), they stimulate discussions and encourage learners to think and speak for themselves.

Learners today, and our group in particular, are exposed to a wide variety of media and technology resources, and therefore often lack the motivation to learn or read in the conventional manner. Research on media literacy shows that the strategies that a good reader brings to a text are similar to those that viewers bring to a visual text (Golden, 2001). Students predict, make connections, ask questions, and interpret when dealing with written or visual texts. In both situations, and they arrive at meaning through the details of character, theme, plot, mood, conflict, and symbolism. However, "Film is much more readily accessible than print because of the visual nature and immediacy of the medium, but the very things that films do for us, good and active readers have to do for themselves" (Golden, 2001). This characteristic of films makes it more entertaining and engaging for students in comparison to the printed text and we decided to exploit this feature.

\section{The context}

India is a country of many languages. ${ }^{1}$ School-going children in India attend one of two kinds of schools: (i) "Englishmedium" schools where English is the "medium of instruction" right from kindergarten onwards, and (ii) "regionalmedium" schools where English is taught as a "subject" as early as in Grade I or as late as in Grade V depending on the state's language policy. ${ }^{2}$ Given the growing importance of English in the context of the globalization of economic opportunities, there is an increasing demand for English. It is no longer being sought just as only a subject or a foreign language, but also as a medium of instruction. This increasing demand for English-medium education has led to a spurt in the number of private "English-medium" schools. Many of these schools are "English-medium" only in name; most often instruction and interaction take place in an Indian language.

\section{The sample}

Forty five students aged 18 to 19 years enrolled in the first year of a B.Tech programme in Hyderabad, India participated in the study. This was a heterogeneous multilingual group consisting of speakers of a variety of Indian languages like Hindi, Telugu, Marathi, Gujrati, Marwari, and Bengali. They came from "English-medium" schools and we found that they could be categorized into two groups:

(i) urban learners who had been exposed to English not only as a subject but also as a medium of instruction. These learners had the added advantage of exposure to English with their teachers, peers and parents, ${ }^{3}$ and

(ii) semi-urban learners who had learnt English in so-called "English-medium" schools where the exposure to English was limited to the language class. Their interaction with their teachers, peers and parents was largely in their respective first languages.

Hence, our class comprised a mixed-ability group with learners at varying levels: some learners in the group had a score of band 9 on the IELTS while others were judged to be at the Intermediate and Basic levels based on an entry level test. These students were enrolled in a four year undergraduate engineering programme. Their attention was devoted almost entirely towards the core subjects they had to study. Although English was one of the core subjects for the first year, our

\footnotetext{
${ }^{1}$ According to the 1991 census, there are 114 languages and 216 mother tongues, each having a speaker strength of 10,000 and above (Vishwanatham, 2001: 299).

${ }^{2}$ A 2003 study by the National Council for Educational Research and Training (NCERT) shows that English is introduced in Class I or III in 26 states or union territories while only 7 states or union territories introduce it as late as Class IV or V (National Focus Group on English - Position paper, 2005: 1).

${ }^{3}$ We found that they read extensively in English - novels, comics, newspapers, and magazines. They also watched a number of television programmes in English.
} 
interaction with them showed that their perception of a language class was limited to one that would help them speak fluently and get rid of the grammatical errors in their spoken language.

\section{The syllabus}

The language syllabus for the first semester comprised entirely of function-based activities. The units were designed by the authors and centered around a theme and a set of language functions. Each unit provided practice in speaking, reading and writing. End-semester evaluation and student portfolios showed that the programme had not succeeded entirely in achieving its objectives of helping students improve their spoken skills.

A brainstorming session was conducted with the students to find out their preferences regarding learning objectives for and the kind of teaching materials to be used for the following semester. Students unanimously expressed a need for developing listening and speaking skills. Considering that the group consisted of engineering students aspiring to work in a global environment, many felt it was essential for them to understand various accents, in particular, the American and the British varieties ${ }^{4}$. With regard to the kind of materials to be used, the students' choices revealed an interest in literary texts and themes such as human psychology. Movie adaptations of popular books that explored the human psyche were also of particular interest. Students suggested the films they would like to watch during the semester, and thus became major stake-holders in the process of curriculum design. Adult L2 learners know their needs and also are capable of articulating them. Thus, the programme showed the success of a syllabus evolved through the process of negotiation (Clarke, 1991) with the learners in contrast with a predetermined one where learners do not have a voice. This accommodates learners' needs as they evolve and change during the course.

\subsection{Why Use Books and their Filmed Version? Rationale}

The syllabus for the second semester therefore was based on an informed decision to address student aspirations of being able to decipher native English in its naturalistic context given that the students tended to look up to the native variety of English. In the Indian context, English is the language of official transaction. However, it is not always the language of social encounters. Even in classrooms, students very often use the home language often code-switching into English instead of carrying on a sustained discourse in English with peers (Vijaya, 2008). On the threshold of their professional world, Indian students often become aware of the sudden leap they need to make from using the home language to predominantly English in the official context. This causes language learning anxiety which makes them feel inadequately equipped for the challenge in future. This anxiety can be used to our advantage using material that the students are well-versed and comfortable with as compared to long reading texts that appear to be ominous. Films seem to be the mantra. Films enjoy a wide viewership among the youth. Added to this is the fact that India is the largest producer of films in the world. The love of films inevitably generates a lot of interest and discussion and is therefore an invaluable source of learning material in such a context (Krashen, 1985).

Films thus provided the relevant material needed to motivate students and involve them in meaningful task-based activities which they perceive as relevant to their needs and to their world which is often very different from the world constructed for them by a language curriculum. During the initial part of the second semester, students put up a stiff resistance to longer texts and displayed a strong unwillingness to read (Williams, 2004). Films, therefore, appeared to be a way to entice them to reading, the sugar coating on the bitter pill of reading. Films served to bring authentic materials into the classroom that provided 'comprehensible input' and stimulated reading (Krashen, 1985). In the second language context, films are the simplest way of bringing the naturalistic context of the target language with its culture into classes. According to Chapple and Curtis (2000), films have many cross-cultural values, enable the development of critical thinking skill and are a rich source of content for language learners. In addition, the motivating feature of films facilitates oral communication skills. Finally, films provide learners exposure to usage (fixed expressions, colloquialisms, redundancy in spoken form, etc.) which is very often not available in classroom interaction. Instances of such usage from the song, I just can't wait to be King (the Lion King), include "vacant expressions", "lights are not all on upstairs", "heart-to-heart", "wouldn't hang about", etc.

Towards the end of the course, during a feedback session, students reported that they had picked up a lot of new words and expressions - lights are not all on upstairs, heart-to-heart, be caught unawares, brushing up on something, working on something, getting out of wing - that they were unaware of prior to the course. Bingo, a word game played in class based on the difficult and/new words in the Prologue of The Beautiful Mind leading to a discussion on synonymy and collocation, e.g., disrespectful, haughty. Vocabulary teaching on this course combined the incidental and contextual approach exemplified in the two tasks above.

By students' own admission, the approach towards learning on the course motivated them to attempt extended reading and writing projects pitched at a level higher than their abilities. The students who embarked upon the course with reservations about reading and a huge reluctance for writing, ended the course with selecting short stories of their own, re-arranging the order of events in the stories and re-writing them in their own language. For instance, a student at B1 (CEFR) level as per our assessment, attempted Conan Doyle's "Dancing Figures". This was in the face of the teachers' fear that the level of the text may be high for the student considering that the language is not contemporary. This was a clear example of the lowering of the "affective filter" induced by motivation provided by the teachers (Krashen, 1985).

\footnotetext{
${ }^{4}$ This reflects the recent socio-economic milieu in India where majority of engineering graduates prefer to seek admission in Universities or work in America. This was also during the call centre boom in urban India with multinational companies setting up offices and language training centres to train their employees to understand and speak in native accents.
} 
5. Methodology \& Materials: Films and Texts

The course finally designed for the second semester was primarily a communications skills course incorporating a play version of the popular novel Dr. Jekyll and Mr. Hyde and an extra module on listening/speaking in the form of movie viewing sessions bearing the student aspirations in mind. Read aloud sessions of the play and language activities based on it were followed by discussions regarding how the play differed from the novel and the film adaptations (Raman and Vijaya, 2009).

Film sessions typically happened over Fridays when students finished their classes for the week and did not have any laboratory sessions. Since learners from the semi-urban background were not used to watching English films, the first four films, The Pianist, Shawshank Redemption, Life is Beautiful, and Catch Me If You Can were used to introduce them to the idea of using films as learning material. Initially, students failed to perceive the link between the movie sessions and language learning material.

To enable students to establish this link, these films were restricted to oral discussions regarding the plot and characters. The films Lion King and A Few Good Men were accompanied by short pre- and post-listening comprehension tasks. Songs from the former were used to teach vocabulary (fixed expressions, collocation, rhyme and style) and grammar. Excerpts from the latter in conjunction with the movie script were used to teach intonation and word and sentential stress patterns. For instance, students enjoyed practicing the intonation and stress in the dialogue below. (See Table 1 below for sample tasks based on the two films.)

Col. Jessup: You don't want the truth. Because deep down, in places you don't talk about at parties, you want me on that wall. You need me on that wall.

Schindler's List

The next set of film-based materials centered around the theme of the holocaust and the film Schindler's List. It was one of the films suggested by the students as many of them had already watched it. The reading materials based on the film consisted of information about Jews, the holocaust, Schindler's life and his role in saving Jews. Spread across the four skills, the tasks consisted of guessing meaning of words in context, comprehension and aspects of text organization (main vs. supporting idea, referencing, and summarizing), oral presentations (on themes of general interest), and pronunciation. Given their interest in improving their pronunciation, they were introduced to the IPA symbols. Their attention was drawn to sounds which appeared similar across L1 and L2 but were actually different in quality, for instance, the use of glides in native English vs. Indian languages and the linking /r/. At the beginning of every class, five minutes were spent on looking up words that interested them. This led to the incorporation of explicit dictionary work in the syllabus.

\section{Beautiful Mind}

The final set of materials film-based material used was built around the theme of bi-polar disorder and the film Beautiful Mind. Once again, this was a film suggested by the students as it echoed the theme of the play Dr. Jekyll and Mr. Hyde. A few of them had already read the novel and a screening of the film was followed by a close reading of the prologue in class. We were pleasantly surprised to find that motivated by the film, a considerable number of students later went on to read the book in its entirety. Pre-watching and while-watching tasks, summarizing, note-making, discussion on themes related to the film, word bingo based on words from the prologue, and writing through summarizing paragraphs were some of the activities taken up.

Table 1. Sample tasks and skill/area taught

\begin{tabular}{lll}
\hline \multicolumn{1}{c}{ Films } & \multicolumn{1}{c}{ Sample tasks } & Skill/area taught \\
\hline A Few Good Men & $\begin{array}{l}\text { Dialogue: } \\
\text { Col. Jessup: You don't want the truth. Because } \\
\text { deep down, in places you don't talk about at } \\
\text { parties, you want me on that wall. You need me } \\
\text { on that wall. }\end{array}$ & $\begin{array}{l}\text { Sentential and word stress } \\
\text { Senten focus } \\
\text { Listening comprehension } \\
\text { vocabulary, pronunciation }\end{array}$ \\
& $\begin{array}{ll}\text { Songs: } \\
\text { Be prepared (fill in the blanks) } \\
\text { I'm gonna be a mighty king }\end{array}$ & $\begin{array}{l}\text { Vocabulary - fixed expressions, } \\
\text { e.g., "vacant expressions", "lights } \\
\text { are not all on upstairs", "heart-to- } \\
\text { heart", "wouldn't hang about". } \\
\end{array}$ \\
& & Collocations; Rhyme \\
\hline
\end{tabular}




\begin{tabular}{|c|c|c|c|c|c|c|}
\hline \multirow[t]{3}{*}{$\begin{array}{l}\text { Schindler's } \\
\text { List }\end{array}$} & \multirow{2}{*}{\multicolumn{5}{|c|}{$\begin{array}{l}\text { 1. Eight sentences have been removed from the story. Choose from the } \\
\text { sentences below (1-4) the one which fits each gap and write the } \\
\text { corresponding number in the box. There is one extra sentence which you do } \\
\text { not need to use. } \\
\text { 2.a. Now read the first paragraph of the Origins of the Holocaust and } \\
\text { underline the topic sentence. } \\
\text { b. Make a list of reasons the author gives for saying, "The ideas and emotions } \\
\text { that lay behind the Holocaust were not new, nor were they uniquely } \\
\text { German." } \\
\text { Sometimes it is impossible to understand a certain sentence without reading a } \\
\text { previous one. (It need not necessarily be the preceding sentence always.) }\end{array}$}} & Organization \\
\hline & & & & & & $\begin{array}{l}\text { Main and } \\
\text { subordinate ideas, } \\
\text { supporting details }\end{array}$ \\
\hline & \multicolumn{5}{|c|}{$\begin{array}{l}\text { From the passage above, consider the following sentence: } \\
\text { 3. Who was this [Oscar Schindler] }\end{array}$} & Reference \\
\hline \multirow[t]{6}{*}{$\begin{array}{l}\text { A Beautiful } \\
\text { Mind }\end{array}$} & \multirow{3}{*}{\multicolumn{5}{|c|}{$\begin{array}{l}\text { Let us look at [the man's] life and find out for ourselves. } \\
\text { Who does "the man" refer to here? You have to read the preceding sentence } \\
\text { to understand the reference. Look at the bold underlined words/phrases in the } \\
\text { text above and connect them to the appropriate reference in the previous } \\
\text { sentences (as shown above). } \\
\text { 1. Here is an extract from the Prologue of the novel "A Beautiful Mind" by } \\
\text { Sylvia Nasar. Read it carefully. Then listen to the words/phrases called out by } \\
\text { the teacher. In the table given to you, find out the meanings for each phrase } \\
\text { being called out. As you hit on the correct meaning write the number of the } \\
\text { corresponding phrase in the box. When you have numbered all the boxes, } \\
\text { raise your hand to indicate that you are done. Your teacher will then see if all } \\
\text { your answers are correct. }\end{array}$}} & $\begin{array}{l}\text { Vocabulary in } \\
\text { context }\end{array}$ \\
\hline & & & & & & Organization \\
\hline & & & & & & \\
\hline & appeared & $\begin{array}{l}\text { capable of } \\
\text { handling } \\
\text { different } \\
\text { areas with } \\
\text { equal skill }\end{array}$ & $\begin{array}{l}\text { resembling } \\
\text { very closely }\end{array}$ & $\begin{array}{l}\text { marked by } \\
\text { lengthy } \\
\text { conversations }\end{array}$ & $\begin{array}{l}\text { flights of } \\
\text { fancy }\end{array}$ & \\
\hline & $\begin{array}{l}\text { good } \\
\text { contrast/ } \\
\text { opposite }\end{array}$ & deep worry & $\begin{array}{l}\text { looked down } \\
\text { upon/ } \\
\text { scorned }\end{array}$ & $\begin{array}{l}\text { cold and } \\
\text { without } \\
\text { feelings }\end{array}$ & $\begin{array}{l}\text { attempting } \\
\text { to please }\end{array}$ & \\
\hline & $\begin{array}{l}\text { always } \\
\text { attempting } \\
\text { to shock or } \\
\text { surprise }\end{array}$ & $\begin{array}{l}\text { forced to be } \\
\text { logical }\end{array}$ & disrespectful & $\begin{array}{l}\text { established } \\
\text { facts/theories }\end{array}$ & $\begin{array}{l}\text { behaving in } \\
\text { a proud } \\
\text { unfriendly } \\
\text { way }\end{array}$ & \\
\hline
\end{tabular}

2. Read paragraphs 1 (of page 14), 1 (of page 17), 3 (of page

18 ) and from the sentences given below for each paragraph

identify the sentence which summarizes each paragraph best.

The first one [3 (page 13)] has been done for you.

\section{Conclusion}

Motivated in the play to experiment with intonational patterns, read-aloud sessions of the play and the films had a reciprocal effect with students using intonational patterns and stress, pronunciation from films for play practice. This also provided opportunities for explicit teaching of pronunciation and transcription. Many of the students overcame their inhibitions and began to 'perform' both in class and outside it with greater ease.

Films familiarized them with the schema of the reading text. Reading tasks became more meaningful than a syllabus consisting of a series of isolated texts. Three versions of the same story-novel, film and play-provide a rich ground for genre based discussions as well as a scaffolding for reading comprehension (Raman and Vijaya, 2009). The post-film discussions clarified a lot of questions that the students had regarding culture, themes and way of life. In this way, the language and the culture of which it is an essential part, ceased to be alien concepts to our learners.

Our observation and student feedback that movie watching had contributed to vocabulary learning is supported by research which shows that a combination of visual and aural input can be as effective as vocabulary learning based on written input alone (Neuman and Koskinen 1992). Koolstra and Beentjes in their 1999 study found that video which links visual input with meaning, presents the language clearly and accurately, and arouses the interest of the viewers could lead to increased vocabulary learning. Taken together, the research indicates that materials which provide visual and aural input such as movies may be conducive to incidental vocabulary learning. The research also indicated that watching movies may be as effective in contributing to incidental vocabulary learning as reading. Studies have also shown that the added visual support provided by films aids listening comprehension (Mueller 1980; Hanley et al. 1995). In addition, the amount of visual input which is presented in films is likely to facilitate comprehension (Rubin 1994; Chapple and Curtis 2000). A major advantage of films is that they provides a large amount of L2 aural input which 
learners are motivated to use as they can see and hear actual instances of language use (Chapple and Curtis 2000; King 2002; Colwell and Braschi 2006). In an EFL context, where learning is largely through the medium of print, films could be used as a means to improve listening skills, learn vocabulary, and focus on specific language points. Used together, films and books could provide written and aural input that promoted greater vocabulary and language learning.

"Contrary to what is often said about the evil nature of money, the message conveyed in Schindler's List-where Schindler wanted to earn more in order to save more Jews-is that it is alright to make money as long as you spend it in a correct manner. Teachers who are able to integrate this sort of popular culture into classroom sessions can provide a valuable bridge between formal and informal education, and help to bring people and places alive.” (Cheung, 2001)

\section{References}

Baharani, T. \& Sim, S. S. (2012). Audiovisual news, cartoons, and films as sources of authentic language input and language proficiency enhancement. The Turkish Online Journal of Educational Technology, 11, 4, 56-64.

Brinton, D. (1991). The use of media in language teaching. Teaching English as a Second or Foreign Language, Boston: Heinle and Heinle Publishers.

Chapple, L., \& Curtis, A. (2000). Content based instruction in Hong Kong: Student responses to film. System, 28,419 33.

Cheung, C. (2001). The use of popular culture as a stimulus to motivate secondary students' English learning in Hong Kong. English Language Teaching Journal, 55 (1), 55- 61.

Clark, C. (2000). Innovative strategy: Concept cartoons. Instructional and learning strategies, 12, 34-45. Clarke, D. F. (1991). The Negotiated Syllabus: What is it and How is it Likely to Work? Applied Linguistics, 12 (1),1328.

Colwell, H., \& Braschi, M. I. (2006). Using films with mixed level ESL classes. Retrieved February 2012, http://www.englishaustralia.com.au/index.cgi?E=hcatfuncs\&PT=s1\&X=getdoc\&Lev1=pub_c07_07\&Lev2=c06_colwe.

Doring, A. (2002). The use of cartoons as a teaching and learning strategy with adult learners. New Zealand Journal of adult learning, 30, 56-62.

Gilmore, A. (2007). Authentic materials and authenticity in foreign language learning. Lang. Teach. 40, 97-118.

Golden, J. (2001). Reading in the Dark: Using film as a tool in the English classroom. Urbana, IL: National Council of Teachers of English.

Hanley, J., Herron, C., \& Cole, S. (1995). Using video as advance organizer to a written passage in the FLES classroom. The Modern Language Journal, 79, 57- 66.

Ismaili, M. (2013). The Effectiveness of Using Movies in the EFL Classroom - A Study Conducted at South East European University. Academic Journal of Interdisciplinary Studies, 2, 4, 121-132.

King, J. (2002). Using DVD feature films in the EFL classroom. Computer Assisted Language Learning, 15, 509 - 23.

Koolstra, C., \& Beentjes, J. (1999). Children's vocabulary acquisition in a foreign language through watching subtitled television programs at home. Educational Technology Research and Development, 47, 51-60.

Krashen, S. (1981). Second language learning and second language acquisition. Oxford: Pergamon press.

Luque, G. (2003). Reading 'Films and' watching 'literary texts: 5 lesson plans for TEFL advanced students' BELLS, Vol. 12. Monograph: The teaching of foreign languages in higher and adult education. Retrieved Feb 2012, http://www.publicacions.ub.edu/revistes/bells12/PDF/art07.pdf

Martinez, A. (2002). Authentic Materials: An Overview.

Melvin, B. S., \& Stout, D. S. (1987). Motivating language learners through authentic materials. In W. Rivers (ed.) Interactive Language Teaching. New York: Cambridge University Press, 44-56. Mueller, G. (1980). Visual contextual cues and listening comprehension: An experiment. Modern Language Journal, $64,335-40$.

National Focus Group on English - Position Paper. (2005). New Delhi: NCERT.

Neuman, B., \& Koskinen, P. (1992). Captioned television as comprehensible input: Effects of incidental word learning from context for language minority students. Reading Research Quarterly, 27, 95-106.

Nunan, D. (1999). Second Language Teaching and Learning. Boston: Heinle and Heinle Publishers.

Raman, M. G., \& Vijaya. (2009). The case of a playful text. In Lilia Savova (Ed.), Using textbooks effectively, TESOL Classroom Practice Series. TESOL: Virginia.

Rubin, J. (1994). A review of second language listening comprehension research. The Modern Language Journal, 78, 199 - 221. 
Rule, A. C., \& Auge, J. (2005). Using humorous cartoons to teach mineral and rock concepts in sixth grade science class. Journal of geosciences education, $53(3), \quad 548-558$. Ryan, S. (1998). Using films to develop learner motivation. The internet TEFL journal, 13(11). Available at: http://iTEFLj.org/articles/Rayan-Film.html. $\quad$ Accessed: $\quad$ November $\quad 10,2015$. Vijaya. (2008). The noun advantage in English as a second language: a study of the natural partitions hypothesis. Unpublished PhD dissertation. CIEFL, Hyderabad.

Webb, S., \& Rodgers, M. (2009). The vocabulary demands of television programs. Language Learning, 59 (2), $335-$ 366.

Webb, S., \& Rodgers, M. (2009). The Lexical Coverage of movies. Applied Linguistics, 30 (3), 407 - 427.

Williams, B. T. (2004). Are we having fun yet? Students, social class and the pleasures of literacy. Journal of Adolescent and Adult Literacy, 48 (4), 338 - 342. 